\title{
Komparasi Model Pembelajaran Konstruktivis Metakognitif Dan Konstruktivis Novick Terhadap Berpikir Kritis Ditinjau Dari Kemampuan Akademik
}

\author{
Baskoro Adi Prayitno \\ Universitas Sebelas Maret Surakarta \\ baskoro_ap@fkip.uns.ac.id \\ Bowo Sugiharto \\ Universitas Sebelas Maret Surakarta \\ bowo@fkip.uns.ac.id
}

\begin{abstract}
The purpose of this study was to investigate, (1) the influence of constructivis metacognitive model compared to constructivis novick, and conventional model toward critical thinking, (2) the influence of academic achievement toward critical thinking, and (3) interaction of learning model and academic achievement toward critical thinking. The sample of this study consisted of 102 eleventh grade student from 3 state senior high schools in Surakarta. The method used in this study is a quasi-experimental research Pretest-Posttest, Non-Equivalent Control Group Design. Anacova was used to analyze the data. Critical thinking tes was administered to the experimental and the control group as pre and post-tests to measure the critical thinking. The result showed that, (1) constructivist metacognitive and constructivist novick are not significantly different but those are significantly different from the conventional model toward critical thinking, (2) Upper academic students have higher critical thiking than lower academic students, (3) There is not interaction of learning model and academic achievement toward critical thinking.
\end{abstract}

Keywords: Critical thinking, constructivist, Academic achievement

\begin{abstract}
Abstrak
Penelitian ini bertujuan menguji, (1) Pengarub konstruktivis metakognitif dibandingkan konstruktivis novick dan konvensional terbadap berpikir kritis,

(2) Pengarub kemampuan akademik terhadap berpikir kritis, (3) Interaksi model pembelajaran dan kemampuan akademik terhadap berpikir kritis. Sampel penelitian 102 siswa kelas XI terdiri dari 51 siswa akademik atas (AA) dan bawah (AB) berasal dari tiga SMA Negeri di Surakarta. Desain penelitian menggunakan kuasi eksperimen Pretest-Posttest, Non-Equivalent Control Group. Analisis data menggunakan anakova. Berpikir kritis diukur menggunakan tes. Temuan penelitian menunjukkan, (1) Model konstruktivis metakognitif dan konstruktivis novick tidak berbeda nyata namun berbeda nyata dengan konvensional terhadap berpikir kritis. (2) Berpikir kritis siswa AA lebih tinggi dibanding siswa AB. (3) Model pembelajaran tidak berinteraksi dengan kemampuan akademik terhadap berpikir kritis.
\end{abstract}

Kata Kunci: Berpikir Kritis, Konstruktivis, Kemampuan Akademik

Permalink/DOI:http://dx.doi.org/10.18326/infsl3.v11i1.25-50 


\section{Pendahuluan}

Berbagai kajian menunjukkan kemampuan berpikir kritis siswa Indonesia memprihatinkan. Survai TIMMS tahun 2003 menempatkan siswa Indonesia urutan 36 dari 45 negara, tahun 2007 Indonesia berada diurutan 41 dari 48 Negara. Survai PISA tahun 2000 menempatkan Indonesia pada peringkat 38 dari 41 Negara. Tahun 2003 Indonesia berada diurutan 38 dari 40 Negara. Tahun 2006 Indonesia berada diurutan 50 dari 57 Negara. Tahun 2009 Indonesia berada diurutan 60 dari 65 Negara (Kurnia \& Fathurohman, 2014). Banyak penelitian yang meyakinkan bahwa kemampuan berpikir kritis siswa di Indonesia memprihatinkan (Anto, Akhdinirwanto, \& Fatmaryanti, 2013; Kurnia \& Fathurohman, 2014; Wulandari, 2011)

Peradaban dunia telah memasuki era pengetahuan. Kemampuan yang diperlukan oleh luaran pendidikan pada era ini adalah kemampuan berpikir tingkat tinggi salah satunya kemampuan berpikir kritis. Kemampuan berpikir kritis merupakan generator lahirnya ide dan inovasi baru sebagai basis terciptanya unggulan baru baik secara komparatif maupun kompetitif dalam persaingan global (Martincová \& Lukešová, 2015). Kemampuan berpikir kritis juga diperlukan oleh luaran pendidikan untuk memecahkan permasalahan kehidupan yang semakin kompleks (ŽivkoviL, 2016).

Rendahnya kemampuan berpikir kritis merupakan permasalahan nasional yang mendesak untuk dipecahkan, jika tidak ingin kualitas berpikir siswa Indonesia semakin terpuruk dibanding dengan negara lain. Akar masalah dari rendahnya kemampuan berpikir kritis adalah model pembelajaran yang kurang mampu memfasilitasi siswa berpikir (Prayitno \& Sugiharto, 2016). Fakta di lapangan, pembelajaran lebih terorientasi pada kegiatan menghafal konsep, ukuran keberhasilan belajar lebih ditekankan pada seberapa banyak siswa menghafal konsep. Akibatnya, siswa tidak terbiasa berpikir kritis.

Diperlukan reorientasi pembelajaran untuk meningkatkan kemampuan berpikir kritis siswa yaitu, dari belajar menghafal konsep menjadi belajar mengkonstruksi konsep, dari belajar berbasis instruksi guru menjadi pembelajaran yang menuntut siswa mengatur dirinya dalam merencanakan, memantau, dan mengevaluasi proses belajarnya, sehingga mereka mampu menjadi pebelajar mandiri. 
Model pembelajaran yang sejalan dengan reorientasi tersebut adalah model berbasis konstruktivis-metakognitif. Model pembelajaran berbasis konstruktivis memandang belajar adalah proses mengkonstruksi pengetahuan, bukan proses menghafal pengetahuan. Siswa dalam mengkonstruksi pengetahuan dituntut mampu merumuskan hipotesis, menguji hipotesis, memanipulasi objek, memecahkan masalah, berdialog, meneliti, mencari jawaban, mengekpresikan gagasan, mengungkap pertanyaan, dan merefleksi diri. Model pembelajaran berbasis konstruktivis menempatkan proses menemukan sebagai bagian penting dalam pembelajaran (Barrouillet, 2015). Model pembelajaran berbasis konstruktivis berpotensi mampu memberdayakan kemampuan berpikir tingkat tinggi termasuk kemampuan berpikir kritis siswa (Duane \& Satre, 2014; Kwan \& Wong, 2015)

Model pembelajaran berbasis metakognitif memandang belajar usaha menyadarkan siswa dalam mengendalikan aktivitas belajarnya (Zhussupova \& Kazbekova, 2016). Siswa yang terampil mengendalikan aktivitas belajarnya lebih bertanggung jawab terhadap dirinya, sehingga mereka mampu merencanakan, memantau, dan mengevaluasi tujuan dan strategi pembelajarannya secara mandiri. Pembelajaran berbasis metakognitif berpotensi melatihkan kemandirian belajar siswa. Strategi metakognitif memberikan pengalaman pada siswa untuk memperhatikan apa yang perlu dipelajari, memantau ingatan apa yang telah dipelajari, mengetahui konsep mana yang belum dipahami, mengingat sesuatu yang penting, dan mencari informasi tambahan untuk memperluas pengetahuannya (Lei, Sun, Lin, \& Huang, 2015).

Model konstruktivis metakognitif dikembangkan (Prayitno, 2014) dengan mengintegrasikan karakter konstruktivis personal Piaget, sosiokultuuralisme Vygotsky, dan diperkuat dengan strategi metakognitif. Model konstruktivis metakognitif mengintegrasikan konsep schemata, konflik kognitif, asimilasi, akomodasi, dan equlibrasi dalam sintaks pembelajaran sebagai representasi karakter konstruktivis personal Piaget. Model konstruktivis metakognitif dalam kerja konstruktivis personal Piaget nya dikelola dalam kelompok kolaboratif yang kuat dengan pelatihan scaffolding sehingga berpotensi mengantarkan siswa dari zona actual ke 
zona potensialnya sebagai representasi karakter sosiokulturalisme Vygotsky. Siswa yang belajar menggunakan model konstruktivis metakognitif akan dibimbing merencanakan, memantau, dan mengevaluasi ketercapain tujuan dan strategi pembelajaran sebagai representasi karakter strategi metakognitif. Pengembangan model pembelajaran konstuktivis-metakognitif secara parsial dinilai tidak berpengaruh maksimal terhadap pemberdayaan kemampuan berpikir dan kemandirian belajar siswa.

Di dunia pembelajaran dikenal model pembelajaran berbasis konstruktivis yang telah mapan yaitu model konstruktivis novick. Model konstruktivis novick dikembangkan berdasarkan teori konstruktivisme personal yang mengusung konsep-konsep skemata, konflik kognitif, asimilasi, akomodasi, dan equilbarasi (Masruroh, Karyanto, \& Indrowati, 2014; Yuliana, Karyanto, \& Marjono, 2013). Komparasi model pembelajaran konstruktivis metakognitif dengan model konstruktivis novick diperlukan untuk menguji keefektifannya terhadap beberapa variabel, seperti menguji keefektifan model konstruktivis metakognitif dibanding konstruktivis novick terhadap kemampuan berpikir kritis siswa AA dan AB.

Berdasarkan latar belakang masalah dapat dirumuskan masalah, (1) Bagaimanakah pengaruh model konstruktivis metakognitif dibandingkan konstruktivis novick, dan konvensional terhadap kemampuan berpikir kritis? (2) Bagaimanakah pengaruh kemampuan akademik terhadap kemampuan berpikir kritis? (3) Apakah ada interaksi antara model pembelajaran dan kemampuan akademik terhadap kemampuan berpikir kritis?

\section{Model Pembelajaran Konstruktivis Metakognitif}

Modelkonstruktivis metakognitif dikembangkanoleh(Prayitno, 2014). Model kontruktivis-metakognitif mengusung teori konstruktivisme personal dan sosial seperti, (1) konsepsi awal, (2) asimilasi, (3) akomodasi, (4) ketidak seimbangan kognitif, (4) zona proximal develpoment (ZPD), (5) scaffolding diperkuat strategi metakognitif seperti keterampilan, (1) perencanaan, (2) memanajemen informasi, (3) memonitor, (4) merevisi, dan (5) mengevaluasi. Sintaks model konstruktivis-metakognitif pada Tabel 1. 
Tabel 1.

Sintaks Model Konstruktivis-Metakognitif

\begin{tabular}{ll}
\hline \multicolumn{1}{c}{ Fase } & \multicolumn{1}{c}{ Kegiatan Guru } \\
\hline Fase I. & - Guru membagi siswa menjadi kelompok heterogen \\
Pembentukan & dalam hal kemampuan akademik, gender, dan hal \\
Tim Kolaboratif & lain yang mungkin ditemukan di dalam kelas. \\
& - Guru menyepakati tentang aturan pemberian \\
& rekognisi tim. \\
\hline Fase II Aktivasi & - Guru mengaktivasi skemata siswa terkait pelajaran \\
Skemata & yang akan dipelajari. Skemata harus memunculkan \\
& konflik kognitif pada siswa. Beberapa cara yang \\
& dapat dilakukan adalah penyajian fenomena atau \\
& mendeskripsikan konsepsi awal siswa. \\
\hline Fase III & Penciptaan konflik kognitif dapat difasilitasi \\
Menciptakan & dengan cara sebagai berikut. (1) Mengajak siswa \\
Konflik Kognitif & berdiskusi kelompok kecil maupun besar. (2) \\
& mendemostrasikan atau mengeksperimenkan yang \\
& membantah konsepsi awal siswa. \\
\hline Fase IV & Pada fase ini siswa dilatihkan untuk terampil \\
Perencanaan & melakukan perencanaan terhadap pembentukan \\
Pembentukan & konsep berdasarkan konflik kognitif yang di \\
Konsep & hadirkan. Indikator empirik yang harus dilakukan \\
& siswa yaitu, (1) menetapkan tujuan pembentukan \\
& konsep yang ingin dicapai, (2) merencanakan \\
& waktu yang akan digunakan untuk mencapai \\
& tujuan, (3) mempersiapkan pengetahuan awal \\
& yang harus mereka kuasai untuk mencapai tujuan, \\
& dan (4) merencanakan dan memutuskan strategi \\
& kognitif yang paling tepat untuk mencapai tujuan. \\
\hline Konsep & Fase pembentukan konsep bertujuan mendorong \\
& terjadinya proses asimilasi dan akomodasi \\
& dalam struktur kognitif siswa sampai terbentuk \\
& keseimbangan kognitif siswa. Pembentukan \\
konsep diorganisasi dalam kelompok kolaboratif. & Pengalaman belajar yang diberikan berupa \\
& demonstrasi, diskusi, atau eksperimen yang \\
& meyakinkan konsepsi awal siswa kurang tepat atau \\
& konsepsi awal mereka dapat diperluas. \\
\hline Pembentukan & \\
&
\end{tabular}




\begin{tabular}{|c|c|}
\hline $\begin{array}{l}\text { Fase V } \\
\text { Presentasi Kelas }\end{array}$ & $\begin{array}{l}\text { - Siswa mempresentasikan hasil kerja di depan } \\
\text { kelas. Presentasi kelas dimanfaatkan untuk } \\
\text { memantau perolehan konsep, memperbaiki, serta } \\
\text { menguatkan konsep yang telah dibangun selama } \\
\text { diskusi kelompok. }\end{array}$ \\
\hline $\begin{array}{l}\text { Fase VI Tes } \\
\text { Individu }\end{array}$ & $\begin{array}{l}\text { - Setelah pembelajaran berlangsung satu KD para } \\
\text { siswa diminta mengerjakan kuis individual. } \\
\text { Para siswa tidak diperbolehkan untuk saling } \\
\text { membantu dalam mengerjakan kuis, sehingga tiap } \\
\text { siswa bertanggungjawab secara individual untuk } \\
\text { memahami materinya. }\end{array}$ \\
\hline $\begin{array}{l}\text { Fase VII } \\
\text { Rekognisi } \\
\text { Kelompok }\end{array}$ & $\begin{array}{l}\text { Menghitung skor kemajuan individual, skor tim, } \\
\text { dan memberikan penghargaan tim. Gagasan } \\
\text { dibalik skor kemajuan individual, skor tim, dan } \\
\text { pemberian penghargaan untuk menanamkan pada } \\
\text { diri siswa bahwa keberhasilan belajar akan dicapai } \\
\text { apabila mereka belajar lebih giat dan memberikan } \\
\text { kinerja yang lebih baik dari sebelumnya. }\end{array}$ \\
\hline
\end{tabular}

Model konstruktivis metakognitif memiliki karakter konstruktivis dan metakognitif. Karakter konstruktivis menuntut siswa mengkonstruksi konsep melalui asimilasi dan akomodasi dengan menggunakan skemata mereka. Karakter konstruktivis menuntut siswa saling berdialog, membelajarkan satu sama lain. Karakter konstruktivis membantu siswa mengembangkan berpikir kritisnya. Karakter konstruktivis menuntut siswa saling belajar satu sama lain melalui kegiatan diskusi. Melalui diskusi akan memunculkan konflik kognitif (Barrouillet, 2015).

Karakter strategi metakognitif berpotensi melatihkan kemandirian belajar. Melalui strategi metakognitif, siswa terbiasa merencanakan, memantau, dan mengevaluasi kognisinya. Melalui karakter metakognitif siswa dituntut untuk merencanakan seperti, (1) menetapkan tujuan yang ingin dicapai, (2) merencanakan waktu yang akan digunakan untuk mencapai tujuan, (3) mempersiapkan pengetahuan awal untuk mencapai tujuan, dan (4) merencanakan dan memutuskan strategi kognitif untuk mencapai tujuan. Siswa dituntut terampil memantau seperti, (1) memantau tujuan yang ingin dicapai, 
(2) memantau waktu yang digunakan, (3) memantau kecukupan pengetahuan awal, dan (4) memantau pelaksanaan strategi kognitif. Siswa dituntut terampil mengevaluasi seperti, (1) mengevaluasi ketercapaian tujuan, (2) mengevaluasi penggunaan waktu, (3) mengevaluasi relevansi pengetahuan awal, dan (4) mengevaluasi efektifitas strategi kognitif yang digunakan (Lei et al., 2015)

\section{Model Pembelajaran Konstruktivis Novick}

Model konstruktivis novick dikembangkan berdasarkan teori konstruktivisme personal yang dikemukakan Piaget. Model konstruktivis novick mengusung konsep-konsep skemata, asimilasi, akomodasi, konflik kognitif, dan equilibrasi dalam sintak-sintak pembelajarannya. Sintak model konstruktivis novick disajikan pada Tabel 2 terdiri dari tiga fase pembelajaran yaitu, (1) exposing alternative framework, (2) creating conceptual conflict, dan (3) encouraging cognitive accommodation. Fase pertama, pembentukan konsep baru melalui asimilasi dan akomodasi memerlukan aktivasi konsepsi awal siswa yang terkait dengan konsep yang akan diajarkan. Mengungkap konsepsi awal siswa merupakan fase pertama dalam sintak model konstruktivis novick. Fase kedua, pada fase ini berdasar konsepsi awal yang telah diperoleh guru merancang konflik konseptual pada siswa. Peran guru pada fase ini membantu siswa mendeskripsikan ideidenya dan membantu siswa menjelaskan ide-idenya pada siswa yang lain. Fase ketiga, guru mendorong terjadinya akomodasi pada struktur kognitif siswa sehingga terbangun konsep baru yang diajarkan. Peran guru dalam fase ini adalah menyediakan pengalaman belajar yang meyakinkan bahwa konsepsi awal siswa kurang tepat. (Masruroh et al., 2014; Yuliana et al., 2013). 
Tabel 2.

Sintaks Model Konstruktivis Novick

\begin{tabular}{|c|c|}
\hline Fase & Kegiatan Guru \\
\hline $\begin{array}{l}\text { Fase I. exposing } \\
\text { alternative } \\
\text { framework }\end{array}$ & $\begin{array}{l}\text { - Guru mengkukap konsepsi awal siswa yang } \\
\text { terkait dengan materi yang akan di ajarkan. } \\
\text { - Cara yang dapat digunakan oleh guru untuk } \\
\text { mengungkap konsepsi awal siswa yaitu, (1) } \\
\text { menghadirkan fenomena, meminta siswa } \\
\text { menelaah fenomena. Fenomena bisa jadi } \\
\text { fenomena yang sudah dikenal siswa atau yang } \\
\text { belum dikenal siswa. Untuk fenomena yang } \\
\text { dikenal siswa guru meminta menjelaskan. } \\
\text { Untuk fenomena yang tidak dikenal siswa } \\
\text { guru meminta siswa meramalkan. (2) meminta } \\
\text { siswa mendeskripsikan konsepsinya dengan } \\
\text { cara misalnya menulis dalam bentuk uraian, } \\
\text { menggambarkan ilustrasi, membentuk model, } \\
\text { membuat peta konsep dan lain-lain. }\end{array}$ \\
\hline $\begin{array}{l}\text { Fase II creating } \\
\text { conceptual } \\
\text { conflict }\end{array}$ & $\begin{array}{l}\text { - Guru berdasarkan konsepsi siswa menciptakan } \\
\text { konflik konseptual. } \\
\text { Penciptaan konflik konseptual dapat dilakukan } \\
\text { oleh guru dengan cara mengajak siswa } \\
\text { berdiskusi dalam kelompok, memberikan } \\
\text { kegiatan pada siswa seperti demonstrasi atau } \\
\text { eksperimen yang hasilnya membantah konsepsi } \\
\text { siswa yang tidak sesuai dengan konsepsi ilmiah. } \\
\text { Perang guru membantu siswa mendeskripsikan } \\
\text { ide-ide siswa dan membimbing siswa dalam } \\
\text { aktivitas demontrasi dan eksperimennya. }\end{array}$ \\
\hline $\begin{array}{l}\text { Fase III } \\
\text { encouraging } \\
\text { cognitive } \\
\text { accommodation }\end{array}$ & $\begin{array}{l}\text { - Guru mendorong terjadinya akomodasi kognitif } \\
\text { pada struktur kognitif siswa. } \\
\text { - Guru menyediakan pengalaman belajar misalnya } \\
\text { percobaan yang lebih meyakinkan siswa } \\
\text { bahwa konsepsinya tidak benar. Untuk bisa } \\
\text { mencapai tahap meyakinkan siswa, guru perlu } \\
\text { menggunakan pertanyaan yang sifatnya menggal } \\
\text { konsepsi siswa. }\end{array}$ \\
\hline
\end{tabular}




\section{Kemampuan Berpikir Kritis}

Kemampuan berpikir kritis menurut (Massa, 2014) adalah proses mental dan strategi siswa untuk menganalisis dan mengevaluasi ide-ide, pilihan-pilihan, dan konsep-konsep untuk mengambil keputusan. Indikator kemampuan berpikir kritis sebagai berikut, (1) Kemampuan merumuskan masalah, (2) Kemampuan berargumen, (3) Kemampuan melakukan deduksi, (4) Kemampuan melakukan induksi, (5) Kemampuan mengevaluasi, dan (6) Kemampuan memutuskan dan mengambil tindakan. Indikator kemampuan merumuskan masalah adalah siswa dapat memformulasikan pertanyaan yang mengarah pada investigasi. Indikator kemampuan berargumen adalah siswa dapat merumuskan argumen sesuai kebutuhan serta dapat menunjukkan perbedaan dan persamaan antara beragam aspek dari tugas yang disimulasikan. Indikator kemampuan deduksi adalah siswa dapat mendeduksi secara logis serta menginterpretasi data secara tepat. Indikator kemampuan induksi adalah siswa mampu menganalisis data, membuat generalisasi, dan menarik simpulan dengan tepat. Indikator kemampuan mengevaluasi adalah siswa mampu mengevaluasi berdasarkan fakta serta memberikan beragam alternatif solusi pemecahan masalah. Indikator kemampuan memutuskan dan mengambil tindakan adalah menentukan jalan keluar dan memilih alternatif kemungkinan yang akan dipilih (Paul, 2014; Stonewater \& Wolcott, 2005).

Menurut (Adey, 1999) cara pemberdayaan kemampuan berpikir kritis melaui pembiasaan siswa untuk bernalar. model pembelajaran berbasis konstruktivis terbukti mampu memberdayakan kemampuan berpikir kritis siswa. Model berbasis konstruktivis memfasilitasi siswa menemukan dan membangun sendiri pengetahuan. Siswa dalam membangun pengetahuan melibatkan kemampuan berpikir kritis. Menurut (Rabu, Aris, \& Tasir, 2013) berpikir kritis dapat dikembangkan melalui pengamatan fenomena. Melalui pengamatan siswa terbiasa melihat dari berbagai sudut pandang dan mencari informasi sebanyak-banyaknya untuk memahami situasi yang dihadapi. 


\section{Metode Penelitian}

Desain penelitian ini menggunakan kuasi eksperiemen PretestPosttest, Non-Equivalent Control Group. Perlakuan model pembelajaran diberikan selama tiga bulan mulai Agustus 2016-Oktober 2016. Guna mengeleminasi variasi subjek penelitian, skor prates kemampuan berpikir kritis digunakan sebagai kovariat. Perlakuan model pembelajaran di kelas dilaksanakan oleh mahasiswa mitra penelitian. Untuk menjamin konsistensi penerapan model pembelajaran selama perlakuan, mahasiswa mitra penelitian dilatih sampai konsisten dalam menerapkan model pembelajaran sebelum perlakuan. Alokasi waktu pembelajaran dan materi pelajaran pada penelitian ini dikendalikan sama. Kesetaraan kemampuan awal siswa di kelas perlakuan dikendalikan melalui uji kesetaraan menggunakan nilai ujian nasional siswa saaat SMP. Keterlaksanaan sintaks model pembelajaran selama perlakuan diobservasi oleh tiga orang guru observer menggunakan pedoman observasi keterlaksanaan sintaks pembelajaran.

Populasi penelitian adalah siswa kelas XII dari delapan SMA Negeri di Surakarta. Sampel sekolah penelitian sebanyak tiga sekolah dengan strata akreditasi yang sama. Sampel siswa terdiri dari siswa berkemampuan akademik atas (AA) dan siswa berkemampuan akademik bawah (AB). Kriteria pengelompokkan siswa kemampuan AA dan AB berdasarkan nilai ujian nasional pada saat siswa SMP. Jumlah sampel siswa AA dan AB masing-masing 51 orang siswa, sehingga total sampel 102 orang siswa.

Kemampuan berpikir kritis diukur menggunakan tes. Indikator kemampuan berpikir kritis yaitu siswa mampu; (1) menginterpretasi, (2) menganalisis, (3) mengevaluasi, (4) menginferensi, (5) mengeksplanasi, dan (6) meregulasi diri (Paul, 2014; Piawa, 2010). Tes berpikir kritis dikembangkan peneliti. Tes berpikir kritis sebelum digunakan di uji indeks validitas dan reliabilitasnya. Sebanyak tiga orang ahli dilibatkan untuk menguji validitas tes kemampuan berpikir kritis. Ahli memvalidasi ketepatan konstruk berpikir kritis dan ketepatan indikator materi pelajaran. Hasil validasi ahli menyatakan tes berpikir kritis dalam kategori valid dengan indeks validitas 3.65. Uji realibilitas tes kemampuan berpikir kritis menggunakan formula 
Cronbach- $\alpha$ menunjukkan nilai reliabilitas tinggi dengan indeks reliabilitas 0.73 , sehingga disimpulkan tes berpikir kritis layak digunakan untuk mengumpulkan data.

Data penelitian dianalisis menggunakan anakova dengan kovariat skor pretes. Sebelum uji anakova, dilakukan uji prasarat statistik parametrik berupa uji normalitas data dan homogenitas varian. Uji normalitas data menggunakan uji Kolmogorov Smirnov. Hasil uji normalitas data berpikir kritis siswa diperoleh data prates sig. 0,065 dan pascates sig. 0,103 lebih besar dari nilai alpha 0.05, sehingga disimpulkan data terdistribusi normal. Uji homogenitas varian terhadap data berpikir kritis diperoleh angka sig. 0,221 lebih besar dari alpha 0,05, sehingga disimpulkan bahwa varian antar kelompok data homogen. Uji LSD digunakan untuk menguji signifikansi perbedaan nilai rata-rata variabel. Penghitungan statistik taraf signifikansi 0.05 .

\section{Analisis}

Hasil uji anakova terhadap variabel kemampuan berpikir kritis pada sumber model pembelajaran, kemampuan akademik, dan interaksi model pembelajaran dengan kemampuan akademik divisualisasikan pada Tabel 5. Merujuk Tabel 5 pada sumbervariansimodel pembelajaran diperoleh angka sig. $=0.000$ lebih kecil dari alpha $0.005(<0,05)$, sehingga disimpulkan ragam model pembelajaran selama perlakuan berpengaruh sangat signifikan terhadap kemampuan berpikir kritis siswa. Temuan ini mengindikasikan terdapat perbedaan karakteristik model pembelajaran dalam meningkatkan kemampuan berpikir kritis siswa. Temuan ini dikuatkan oleh (Lu, Hong, \& Tseng, 2015) yang menyatakan setiap model pembelajaran memiliki potensi berbeda dalam meningkatkan hasi belajar siswa termasuk meningkatkan kemampuan berpikir kritis. Perbedaan tersebut disebabkan oleh perbedaan karakteristik sintaks model pembelajaran. Perbedaan karakteristik sintaks model konstruktivis metakognitif, konstruktivis novick, dan konvensional diduga menyebabkan kemampuan berpikir kritis siswa berbeda sangat signifikan dalam penelitian ini. 
Tabel 5.

Uji Anakova Pengaruh Perlakuan terhadap Berpikir Kritis

\begin{tabular}{llllll}
\hline Source & Sum of Squares & $\mathrm{df}$ & Mean Square & $\mathrm{F}$ & Sig. \\
\hline Corrected Model & $12419.801^{\mathrm{a}}$ & 6 & 2069.967 & 21.632 & .000 \\
Intercept & 14458.126 & 1 & 14458.126 & 151.095 & .000 \\
Pretest Kognitive & 553.818 & 1 & 553.818 & 5.788 & .018 \\
Model Pembelajaran & 8578.005 & 2 & 4289.002 & 44.822 & .000 \\
Akademik & 323.533 & 1 & 323.533 & 3.381 & .069 \\
Model Pembelajaran & 288.715 & 2 & 144.357 & 1.509 & .226 \\
*Akademik & 9090.447 & 95 & 95.689 & & \\
Error & 472513.250 & 102 & & & \\
Total & 21510.248 & 101 & & & \\
Corrected Total & A 25 Sijusted $R$ Squared $=.551)$ & & &
\end{tabular}

Untuk mengetahui urutan model pembelajaran yang paling efektif dalam meningkatkan kemampuan berpikir kritis dilakukan uji LSD. Hasil uji LSD divisualisasikan pada Tabel 6.

Tabel 6.

Kemampuan Berpikir Kritis pada Sumber Model Pembelajaran

\begin{tabular}{lllllc}
\hline Model Pembelajaran & XBK $^{*}$ & YBK $^{*}$ & Selisih & CBK $^{*}$ & Notasi \\
\hline Konvensional & 18.162 & 66.495 & 48.333 & 49.808 & $\mathrm{a}$ \\
Konstruktivis Novick & 20.809 & 72.323 & 51.514 & 71.754 & $\mathrm{~b}$ \\
Konstruktivis Metakognitif & 20.294 & 74.808 & 54.514 & 74.517 & $\mathrm{~b}$ \\
\hline
\end{tabular}

*) XBK: rata-rata pretes berpikir kritis; YBK: rata-rata pascates berpikir kritis; CBK: rata-rata terkoreksi kemampuan berpikir kritis

Tabel 6 menunjukkan model pembelajaran konstruktivis metakognitif dan konstruktivis novick tidak berbeda nyata dalam meningkatkan kemampuan berpikir kritis lebih unggul dibanding model konvensional. Model konvensional memiliki kemampuan meningkatkan berpikir kritis paling rendah dibanding model konstruktivis metakognitif dan konstruktivis novick. Siswa yang belajar menggunakan model konstruktivis metakognitif memiliki rata-rata kemampuan berpikir kritis paling tinggi dibanding siswa 
yang belajar menggunakan model konstruktivis novick maupun konvensional. Selisih peningkatan skor kemampuan berpikir kritis dari prates ke pascates menunjukkan model konstruktivis metakognitif dan konstruktivis novick lebih mampu mengangkat kemampuan berpikir kritis siswa dibanding model konvensional.

Model konstruktivis metakognitif dikembangkan dengan mengintegrasikan tiga aliran teori pembelajaran yaitu; (1) konstruktivisme personal Piaget, (2) Sosiokulturalisme Vygotsky, dan (3) Strategi metakognitif. Karakteristik konstruktivisme personal Piaget pada model konstruktivis metakognitif menuntut siswa mengkonstruksi sendiri konsep melalui jalur asimilasi dan akomodasi (Barrouillet, 2015; Gunduz \& Hursen, 2015) Karakteristik sosiokulturalisme Vigotsky pada model konstruktivis metakognitif menjamin scaffolding antar siswa melalui diskusi kelompok kolaboratif berjalan lebih efektif (Lu et al., 2015; Rahmani \& Abbas, 2014; Rahmani, Abbas, \& Alahyarizadeh, 2013). Karakteristik strategi metakognitif pada model konstruktivis metakognitif membiasakan siswa dalam pembelajaran untuk; (1) Merencanakan dan menetapkan tujuan pembelajaran secara mandiri, (2) Merencanakan dan memutuskan strategi kognitif yang paling sesuai dengan dirinya untuk mencapai tujuan pembelajaran yang telah ditetapkan, (3) Memantau keefektivan pelaksanaan strategi kognitif yang dipilihnya dalam mencapai tujuan pembelajaran yang telah ditetapkan, dan (4) Mengevaluasi ketercapaian tujuan pembelajaran yang telah ditetapkan dan mengevaluasi keefektifan strategi tersebut (Kisac \& Budak, 2014; Lei et al., 2015)

Karakter konstruktivis personal Piaget pada model konstruktivis metakognitif berpotensi besar mampu melatihkan indikator-indikator kemampuan berpikir krtis seperti kemampuan interpretasi, analisis, evaluasi, inferensi, dan eksplanasi. Keefektifan pelatihan pada aspek kemampuan berpikir kritis tersebut dikarenakan pada model pembelajaran konstruktivis metakogitif siswa dituntut untuk mengkonstruksi sendiri konsep melalui aktivitas asimilasi dan akomodasi (Chaijaroen, Kanjug, \& Samat, 2012; Kwan \& Wong, 2015). Karakter strategi metakognitif pada model konstruktivis metakognitif berpotensi besar melatihkan kemampuan berpikir kritis pada domain regulasi diri (Nosratinia \& Adibifar, 2014; Tajalli 
\& Satari, 2013). Karakter sosiokulturalisme pada model konstruktivis metakognitif memfasilitasi siswa bekerja dalam kelompok kolaboratif yang kuat dengan dialog, diskusi, debat, sekaligus tutorial sebaya sehingga berpotensi mampu menguatkan penguasaan siswa terhadap indikator-indikator berpikir kritis (Barrouillet, 2015). Karakterkarakter tersebut menyebabkan siswa yang belajar menggunakan model konstruktivis metakognitif memiliki rata-rata kemampuan berpikir kritis paling tinggi dibandingkan model konstruktivis Novick dan konvensional.

Model konstruktivis novick merupakan turunan dari teori konstruktivisme personal Piaget yang mengusung konsep skemata, asimilasi, akomodasi, dan equilibrasi. Model konstruktivis novick menuntut siswa untuk mengkonstruksi konsep melalui jalur asimilasi dan akomodasi (Barrouillet, 2015). Aktivitas scaffolding dan pelatihan strategi metakognitif pada model konstruktivis novick tidak didesain secara sengaja. Akibatnya, aktivitas scaffolding dan pelatihan strategi metakognitif pada model konstruktivis novick tidak sekuat pada model konstruktivis metakognitif. Karakteristik ini menyebabkan pelatihan kemampuan berpikir kritis pada model konstruktivis novick lebih banyak dilatihkan melalui aktivitas asimilasi dan akomodasi. Siswa yang belajar menggunakan model konstruktivis novick berdasarkan rata-rata kemampuan berpikir kritis menduduki peringkat kedua lebih tinggi dibanding model konvensional.

Meskipun terdapat perbedaan rata-rata kemampuan berpikir kritis antara siswa yang belajar menggunakan model konstruktivis metakognitif dan konstruktivis Novick setelah uji LSD menunjukkan kemampuan berpikir kritis tersebut tidak berbeda signifikan. Diduga karakteristik konstruktivisme personal Piaget pada model konstruktivis metakognitif dan konstruktivis novick yang menuntut siswa mengkonstruksi konsep melalui aktivitas asimilasi dan akomodasi merupakan aktivitas yang paling kuat dalam melatihkan indikator kemampuan berpikir kritis dibandingkan sumbangan dari aktivitas kerja kelompok kolaboratif, scaffolding, dan strategi metakognitif. 
Model konvensional pada penelitian ini merujuk pada model pembelajaran langsung yaitu pembelajaran yang lebih banyak didominasi oleh guru. Guru menyampaikan materi pelajaran pada siswa melalui slide power point dilanjutkan dengan diskusi dan tanya jawab dengan siswa. Model konvensional memposisikan siswa sebagai penerima informasi, siswa mendengarkan penjelasan guru sesekali bertanya tentang konsep yang belum mereka pahami. Siswa pada model konvensional cenderung belajar menghafal konsep. Siswa kurang dituntut berpikir tingkat tinggi selama pembelajaran, akibatnya kemampuan berpikir kritis siswa tidak terberdayakan dengan baik (Prayitno \& Sugiharto, 2016). Siswa yang belajar menggunakan model konvensional berdasarkan rata-rata kemampuan berpikir kritis dan hasil uji LSD menduduki posisi terbawah dibanding siswa yang belajar menggunakan model konstruktivis metakognitif dan model konstruktivis novick.

Tabel 5 pada sumber variansi kemampuan akademik diperoleh angka sig.= 0,69 lebih besar dari alpha 0,05 (>0,05), sehingga disimpulkan kemampuan akademik tidak berpengaruh signifikan terhadap kemampuan berpikir kritis. Temuan penelitian tidak sejalan dengan (Prayitno \& Sugiharto, 2016) yang menyatakan, siswa AA memiliki kemampuan merespon pembelajaran lebih baik dibandingkan siswa AB. Siswa AA dengan kemampuan yang dimilikinya lebih mudah memahami materi pelajaran dibandingkan siswa AB. Keunggulan siswa AA dalam merespon dan memahami pelajaran dibandingkan siswa $\mathrm{AB}$ menyebabkan kemampuan berpikir kritis siswa AA lebih tinggi dibandingkan siswa AB.

Temuan ini juga tidak sejalan dengan yang menyatakan (Ozden, 2008), siswa pada kelas konvensional bervariasi dalam bakat, ketekunan, dan kemampuan menerima pelajaran. (Amiruddin, Samad, \& Othman, 2015) menyatakan, perbedaan variasi tersebut disebabkan oleh faktor keluarga, sekolah, dan psikososial. Dukungan keluarga, iklim kelas yang penuh dengan kompetisi, pelabelan negatif, self esteem, dan self-concept sosial yang rendah menyebabkan munculnya variasi tersebut. Siswa di kelas yang terdistribusi normal dalam bakat, ketekunan, dan kemampuan menerima pelajaran, jika diberikan kualitas pembelajaran, materi pelajaran, dan alokasi waktu belajar yang sama, maka prestasi 
belajar siswa akan terdistribusi normal pula. Siswa terbagi menjadi siswa berprestasi belajar tinggi (siswa AA) dan siswa berprestasi belajar rendah (siswa $\mathrm{AB}$ ).

Faktor-faktor yang diduga menyebabkan temuan penelitian bertentangan dengan teori yaitu faktor bias dalam pengelompokkan siswa AA dan AB. Pengelompokkan siswa AA dan AB pada penelitian ini menggunakan nilai UN siswa saat SMP. Pengelompokkan siswa AA dan AB pada penelitian ini dengan cara mengurutkan siswa mulai dari nilai UN tertinggi sampai terendah kemudian dicari rata-rata nilai UN siswa. Siswa yang memiliki nilai di atas rata-rata dimasukkan pada kelompok siswa AA sebaliknya siswa yang memiliki nilai UN di bawah rata-rata dimasukan pada kelompok siswa AB. Uji beda menggunakan statistik seharusnya dilakukan oleh peneliti untuk meyakinkan pengelompokkan siswa $\mathrm{AA}$ dan $\mathrm{AB}$ memang berbeda sangat signifikan dalam kemampuan akademiknya. Tidak diketahui perbedaan kemampuan $\mathrm{AA}$ dan $\mathrm{AB}$ melalui penghitungan statistic boleh jadi menyebabkan temuan penelitian bertentangan dengan teori.

Faktor lain yang diduga menyebabkan temuan penelitian bertentangan dengan teori adalah bias teori yang digunakan. Keefektifan scaffolding pada model pembelajaran selama perlakuan menyebabkan kesenjangan kemampuan berpikir kritis antara siswa $\mathrm{AA}$ dan $\mathrm{AB}$ dapat diperkecil. Siswa AB dapat menguasai pelajaran jika memperoleh scaffolding dari guru dan teman sebayanya. Scaffolding oleh guru dan teman sebaya mendorong siswa AB mampu memasuki zona potensialnya. Pembelajaran yang mampu memfasilitasi scaffolding yang efektif menyebabkan siswa $\mathrm{AB}$ memasuki zona perkembangan proksimalnya, akibatnya kesenjangan kemampuan berpikir kritis antara siswa $\mathrm{AA}$ dan $\mathrm{AB}$ dapat diperkecil, sehingga temuan penelitian menunjukkan tidak ada pengaruh kemampuan akademik terhadap kemampuan berpikir kritis siswa (Lin, Hong, \& Lawrenz, 2012; Lu et al., 2015; Rahmani et al., 2013). Namun, jika dilihat dari rata-rata skor terkoreksi kemampuan berpikir kritis pada sumber kemampuan akademik menunjukkan siswa AA memiliki rata-rata kemampuan berpikir kritis terkoreksi lebih tinggi dibanding siswa AB. Temuan ini secara kasar menguatkan teori yang menyatakan bahwa siswa AA lebih unggul dibandingkan siswa AB 
dalam prestasi belajar.

\section{Tabel 7}

\section{Berpikir Kritis pada Sumber Kemampuan Akademik}

\begin{tabular}{lcccc}
\hline $\begin{array}{l}\text { Kemampuan } \\
\text { Akademik }\end{array}$ & XBK $^{*}$ & YBK $^{*}$ & Selisih & CBK $^{*}$ \\
\hline Bawah (AB) & 17.206 & 63.049 & 45.843 & 64.426 \\
Atas (AA) & 22.304 & 69.941 & 47.637 & 68.564 \\
\hline
\end{tabular}

*) XBK: rata-rata pretes berpikir kritis; YBK: rata-rata pascates berpikir kritis; CBK: rata-rata terkoreksi berpikir kritis

Tabel 5 pada sumber variansi interaksi model pembelajaran dengan kemampuan akademik diperoleh angka sig. $=0.226$ lebih besar dari alpha $0.005(>0,05)$, sehingga disimpulkan tidak ada interaksi ragam model pembelajaran dengan kemampuan akademik terhadap kemampuan berpikir kritis siswa. Untuk mengetahui posisi interaksi model pembelajaran dengan kemampuan akademik dilakukan uji LSD seperti pada Tabel 8

\section{Tabel 8}

Interaksi Model dengan Kemampuan Akademik terhadap Kemampuan Berpikir Kritis

\begin{tabular}{lcccccc}
\hline \multicolumn{1}{c}{ Model } & Akad $^{*}$ & $\mathrm{XBK}^{*}$ & YBK $^{*}$ & Selisih & CBK $^{*}$ & Notasi \\
\hline Konvensional & (AB) & 15.441 & 41.471 & 26.030 & 46.471 & $\mathrm{a}$ \\
Konvensional & (AA) & 20.882 & 55.588 & 34.706 & 58.235 & $\mathrm{~b}$ \\
$\begin{array}{l}\text { Konstruktivis } \\
\text { Novick }\end{array}$ & (AB) & 17.500 & 66.912 & 49.412 & 70.483 & $\mathrm{c}$ \\
$\begin{array}{l}\text { Konstruktivis } \\
\text { Novick }\end{array}$ & (AA) & 24.118 & 73.088 & 48.970 & 73.025 & $\mathrm{~cd}$ \\
$\begin{array}{l}\text { Konstruktivis } \\
\text { Metakognitif }\end{array}$ & (AB) & 18.677 & 79.559 & 60.892 & 73.994 & $\mathrm{~d}$ \\
$\begin{array}{l}\text { Konstruktivis } \\
\text { Metakognitif }\end{array}$ & (AA) & 21.911 & 80.294 & 58.383 & 75.041 & $\mathrm{~d}$ \\
\hline
\end{tabular}

") Akad: Kemampuan akademik; XBK: rata-rata prates berpikir kritis; YBK: ratarata pasca tes berpikir kritis; CBK: rata-rata terkoreksi berpikir kritis

Tabel 8 menunjukkan model konstruktivis metakognitif AA, konstruktivis metakognitif $\mathrm{AB}$, dan konstruktivis novick AA berbeda 
nyata lebih tinggi dibandingkan konstruktivis novick AB, Konvensional AA dan konvensional AB terhadap kemampuan berpikir kritis. Model konstruktivis novick $\mathrm{AB}$ berbeda nyata lebih tinggi dibandingkan model konvensional AA dan AB terhadap kemampuan berpikir kritis. Model konvensional AA berbeda nyata lebih tinggi dibanding model konvensional $\mathrm{AB}$ terhadap kemampuan berpikir kritis.

Siswa yang belajar menggunakan model konstruktivis metakognitif kemampuan berpikir kritisnya dilatihkan melalui tiga jalur yaitu; (1) Karakteristik konstruktivis personal Piaget. Guru pada awal pembelajaran mengaktivasi schemata awal siswa terkait konsep yang akan diajarkan, kemudian guru merancang konflik kognitif yang mengantarkan siswa untuk mengkonstruksi sendiri pengetahuan melalui jalur akomodasi atau asimilasi (Barrouillet, 2015; Gunduz \& Hursen, 2015). (2) Karakteristika sosiokulturalisme Vygotsky. Siswa dalam aktivitas mengkonstruksi pengetahuan dikelola dalam kelompok kolaboratif yang terencana, sehingga scaffolding, dialog, diskusi berlangsung lebih optimal (Bodrova \& Leong, 1998; Rahmani et al., 2013). (3) Karakteristik strategi metakognitif. Siswa dalam aktivitas mengkonstruksi pengetahuan dipandu strategi metakognitif yang tersurat tegas pada sintaks model pembelajaran, sehingga siswa terbiasa berlatih menetapkan tujuan, menetapkan strategi pencapaian tujuan, dan monitoring strategi dan pencapaian tujuan (Lei et al., 2015; Zhussupova \& Kazbekova, 2016). Tiga jalur pelatihan ini menempatkan model konstruktivis metakognitif paling tinggi dalam melatihkan kemampuan berpikir kritis pada siswa AA dan AB dibandingkan model konstruktivis novick $\mathrm{AB}$, konvensional $\mathrm{AA}$ dan $\mathrm{AB}$.

Berbeda dengan model konstruktivis metakognitif, kemampuan berpikir kritis pada model konstruktivis novick lebih banyak dilatihkan melalui karakteristik konstruktivisme personal Piaget. Guru di awal pembelajaran mengaktivasi pengetahuan lama siswa yang terkait dengan materi yang akan diajarkan. Berdasarkan pengetahuan lama siswa, guru menghadirkan konflik kognitif untuk membentuk ketidakseimbangan kognitif pada diri siswa, kemudian siswa belajar mengkonstruksi konsep secara mandiri melalui jalur asimilasi atau akomodasi (Barrouillet, 2015). Kegiatan pengkonstruksian konsep dilakukan dalam kelompok tradisional. 
Diakhir pembelajaran siswa mempresentasikan hasil konstruksinya di bawah supervise guru. Aktivitas ini menempatkan model konstruktivis novick $\mathrm{AA}$ dan $\mathrm{AB}$ lebih unggul dibandingkan model konvensional AA dan AB.

Model konvensional menempatkan guru sebagai sumber informasi utama dalam pembelajaran. Pembelajaran model konvensional didominasi kegiatan transfer pengetahuan dari guru ke siswa. Model konvensional kurang memfasilitasi siswa mengembangkan kemampuan berpikir kritisnya. Pembelajaran pada model konvensional dilaksanakan pada kelas klasikal dengan suasana kompetisi dan isolasi. Pembelajaran yang kuat dengan suasana kompetisi dan isolasi menyebabkan kegiatan saling membelajarkan tidak terjadi, akibatnya terjadi kesenjangan kemampuan berpikir kritis antara siswa AA dan AB (Prayitno \& Sugiharto, 2016). Siswa AA lebih mampu dalam menguasai kemampuan berpikir kritis dibandingkan siswa AB. Model konvensional diimplementasikan pada kelompok tradisional. Pembagian anggota kelompok tradisional dilakukan dengan tidak memperhatikan keragaman siswa. Pembelajaran yang tidak memperhatikan keragaman siswa seperti keragaman kemampuan akademik, keragaman kemampuan menerima pembelajaran, dan keragaman kebutuhan waktu belajar akan menyebabkan siswa AA akan lebih mampu berpikir kritis dibandingkan siswa AB.

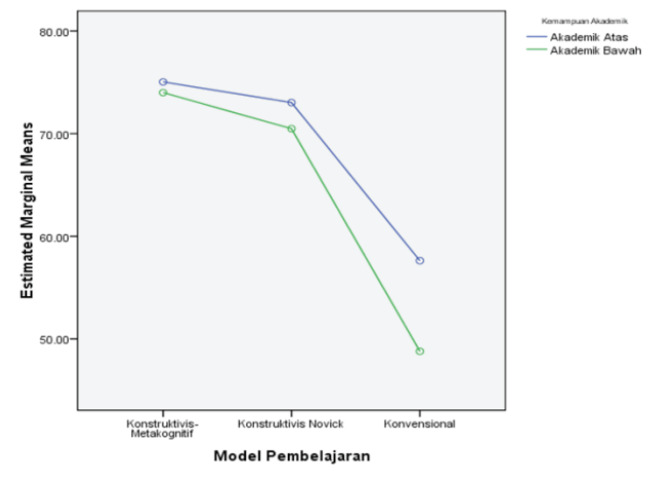

Gambar 1.

Interaksi Model Pembelajaran dan Kemampuan Akademik 
Tabel 8 menunjukkan kemampuan berpikir kritis siswa AA dan AB pada siswa yang belajar menggunakan model konstruktivis metakognitif tidak berbeda nyata. Siswa AB pada model pembelajaran konstruktivis metakognitif mampu mensejajarkan kemampuan berpikir kritisnya dengan siswa AA yang belajar menggunakan model konstruktivis novick. Kemampuan berpikir kritis siswa AA dan AB pada siswa yang belajar menggunakan model konstruktivis novick tidak berbeda nyata. Kemampuan berpikir kritis siswa AA lebih tinggi dibanding $\mathrm{AB}$ yang belajar menggunakan model konvensional. Selisih peningkatan ratarata kemampuan berpikir kritis dari pra tes ke pasca tes pada model konstruktivis metakognitif $\mathrm{AB}$ menduduki posisi tertinggi diikuiti model konstruktivis metakognitif AA, konstruktivis novick $\mathrm{AB}$, konstruktivis novick AA, konvensional AA dan AB. Temuan ini mengindikasikan model konstruktivis-metakognitif memiliki kemampuan mengangkat kemampuan berpikir kritis siswa AB lebih baik dibanding model dan konstruktivis novick dan konvensional sebagaimana ditunjukkan pada Gambar 1.

Gambar 1 menunjukkan model konstruktivis metakognitif lebih mampu memperkecil kesenjangan berpikir kritis antara siswa AA dan AB dibanding model konstruktivis novick dan konvensional. Temuan ini mengindikasikan siswa yang belajar menggunakan model konstruktivis metakognitif telah berhasil melampuai zona aktualnya memasuki zona potensialnya. Model konstruktivis metakognitif memiliki karakter sosiokulturalisme Vygotsky yang kuat dengan scaffolding melalui kerja kelompok kolaboratif. Pembelajaran model konstruktivis metakognitif yang dikelola dalam keompok kolaboratif menuntut siswa AA memberikan scaffolding pada siswa AB. Diduga scaffolding yang efektif siswa AA pada siswa AB mampu mengantarkan siswa $\mathrm{AB}$ mencapai zona proksimal developmentnya lebih tinggi dibanding siswa yang belajar menggunakan model konstruktivis novick dan konvensional (Bodrova \& Leong, 1998). 


\section{Kesimpulan}

Model konstruktivis metakognitif dan konstruktivis novick tidak berbeda nyata, namun berbeda nyata dengan model konvensional dalam meningkatkan kemampuan berpikir kritis. Kemampuan berpikir kritis siswa AA dan AB tidak berbeda nyata secara signifikan. Model pembelajaran konstruktivis metakognitif dan konstruktivis novick mampu memperkecil kesenjangan kemampuan berpikir kritis antara siswa AA dan AB. Model konvensional menyebabkan kesenjangan kemampuan berpikir kritis antara siswa AA dan AB. Model konstruktivis metakognitif memiliki kemampuan memperkecil kesenjangan kemampuan berpikir kritis antara siswa $\mathrm{AA}$ dan $\mathrm{AB}$ paling tinggi dibanding model konstruktivis novick dan konvensional.

Model konstruktivis metakognitif dan konstruktivis novick andal dalam melatihkan kemampuan berpikir kritis pada siswa AA dan $\mathrm{AB}$, guru perlu mencoba menerapkannya dalam pembelajaran di kelas. Aktivitas scaffolding yang terencana dengan melibatkan siswa AA perlu dipertimbangkan guru, karena terbukti mampu memperkecil kesenjangan kemampuan berpikir kritis antara siswa AA dan AB. Pembelajaran berbasis kompetisi seperti pada model konvensional menyebabkan terjadinya kesenjangan kemampuan berpikir kritis antara siswa $\mathrm{AA}$ dan $\mathrm{AB}$. 


\section{Daftar Pustaka}

Adey, P. (1999). The Science of Thinking, and Science for Thinking: A Description of Cognitive Acceleration through Science Education (CASE), 1-40. Retrieved from http://eric.ed.gov/ ERICWebPortal/recordDetail?accno=ED442622

Amiruddin, M. H., Samad, N. A., \& Othman, N. (2015). An Investigation Effects of Mastery Learning Strategy on Entrepreneurship Knowledge Acquisition among Aboriginal Students. Procedia Social and Behavioral Sciences, 204(November 2014), 183-190. https://doi.org/10.1016/j.sbspro.2015.08.131

Anto, A. A., Akhdinirwanto, R. W., \& Fatmaryanti, S. D. (2013). Pemanfaatan Model Problem Posing untuk Peningkatan Berpikir Kritis Siswa. Radiasi, 2(1), 4-6.

Barrouillet, P. (2015). Theories of cognitive development: From Piaget to today. Developmental Review, 38, 1-12. https://doi. org/10.1016/j.dr.2015.07.004

Bodrova, E., \& Leong, D. (1998). Scaffolding Emergent Writing in the Zone of Proximal Development. Literacy Teaching and Learning, 3(2), 1-19. Retrieved from http://www.readingrecovery.org/ pdf/Journals/LTL/LTL_Vol3_No2-1998/LTL_3.2-Bodrova-Leong. pdf

Chaijaroen, S., Kanjug, I., \& Samat, C. (2012). The Study of Learners' Critical Thinking Potential, Learning with Innovation Enhancing Thinking Potential. Procedia - Social and Behavioral Sciences, 46, 3415-3420. https://doi.org/10.1016/j.sbspro.2012.06.076

Duane, B. T., \& Satre, M. E. (2014). Utilizing constructivism learning theory in collaborative testing as a creative strategy to promote essential nursing skills. Nurse Education Today, 34(1), 31-34. https://doi.org/10.1016/j.nedt.2013.03.005

Gunduz, N., \& Hursen, C. (2015). Constructivism in Teaching and Learning; Content Analysis Evaluation. Procedia - Social and Behavioral Sciences, 191(392), 526-533. https://doi. 
org/10.1016/j.sbspro.2015.04.640

Kisac, I., \& Budak, Y. (2014). Metacognitive Strategies of the University Students with Respect to their Perceived Self-confidence Levels about Learning. Procedia-Social and Behavioral Sciences, 116, 3336-3339. https://doi.org/10.1016/j.sbspro.2014.01.759

Kurnia, F., \& Fathurohman, A. (2014). Analisis bahan ajar fisika sma kelas xi di kecamatan indralaya utara berdasarkan kategori literasi sains, 1(1), 43-47.

Kwan, Y. W., \& Wong, A. F. L. (2015). Effects of the constructivist learning environment on students' critical thinking ability: Cognitive and motivational variables as mediators. International Journal of Educational Research, 70, 68-79. https://doi. org/10.1016/j.ijer.2015.02.006

Lei, P. L., Sun, C. T., Lin, S. S. J., \& Huang, T. K. (2015). Effect of metacognitive strategies and verbal-imagery cognitive style on biology-based video search and learning performance. Computers and Education, 87, 326-339. https://doi. org/10.1016/j.compedu.2015.07.004

Lin, H. S., Hong, Z. R., \& Lawrenz, F. (2012). Promoting and scaffolding argumentation through reflective asynchronous discussions. Computers and Education, 59(2), 378-384. https:// doi.org/10.1016/j.compedu.2012.01.019

Lu, C., Hong, J., \& Tseng, Y. (2015). The effectiveness of inquirybased learning by scaffolding students to ask " 5 Why" questions, (October), 1-26.

Martincová, J., \& Lukešová, M. (2015). Critical Thinking as a Tool for Managing Intercultural Conflicts. Procedia - Social and Behavioral Sciences, 171, 1255-1264. https://doi.org/10.1016/j. sbspro.2015.01.239

Masruroh, R. D., Karyanto, P., \& Indrowati, M. (2014). Studi Komparasi Pemahaman Konsep Sistem Pernapasan Manusia Melalui Penerapan Pembelajaran Konstruktivisme tipe Novick 
Dipadu Concept Map dan Ceramah Bervariasi A Comparative Study on the Comprehension of Human Respiration System Concept using the Novick T, 7, 26-31.

Massa, S. (2014). The Development Of Critical Thinking In Primary School: The Role of Teachers' Beliefs. Procedia -Social and Behavioral Sciences, 141(2014), 387-392. https://doi. org/10.1016/j.sbspro.2014.05.068

Nadiah Wulandari, D. S. (2011). Pengaruh Problem Based Learning Dan Kemampuan Berpikir Kritis Terhadap Hasil Belajar Mahasiswa. Tekno-Pedagogi, 1(1), 14-24.

Nosratinia, M., \& Adibifar, S. (2014). The Effect of Teaching Metacognitive Strategies on Field-dependent and Independent Learners' Writing. Procedia - Social and Behavioral Sciences, 98, 1390-1399. https://doi.org/10.1016/j.sbspro.2014.03.557

Ozden, M. (2008). Improving Science and Technology Education Achievement Using Mastery Learning Model. World Applied Sciences Journal, 5(1), 62-67. Retrieved from http://idosi.org/ wasj/wasj5(1)/10.pdf

Paul, S. A. (2014). Assessment of critical thinking: A Delphi study. Nurse Education Today, 34(11), 1357-1360. https://doi. org/10.1016/j.nedt.2014.03.008

Piawa, C. Y. (2010). Building a test to assess creative and critical thinking simultaneously. Procedia - Social and Behavioral Sciences, 2(2), 551-559. https://doi.org/10.1016/j. sbspro.2010.03.062

Prayitno, B. A. (2014). Potensi Sintaks Model Pembelajaran Konstuktuvis-Metakognitif dalam Melatihkan Berpikir dan Kemandirian Belajar Siswa. Prosiding SNPS (Seminar Nasional Pendidikan Sains), 1(1), 235-245.

Prayitno, B. A., \& Sugiharto, B. (2016). Keefektivan Integrasi Sintaks Inkuiri Terbimbing Dan Stad (Instad) Untuk Memperkecil Kesenjangan Keterampilan Metakognisi Siswa Akademik Atas 
Dan Bawah. Inferensi, 9(2), 305-328. https://doi.org/10.18326/ infs13.v9i2.305-328

Rabu, S. N. A., Aris, B., \& Tasir, Z. (2013). Teaching Critical thinking through Online Instructor Scaffolding: A Conceptual Framework. Procedia - Social and Behavioral Sciences, 97, 314-319. https:// doi.org/10.1016/j.sbspro.2013.10.239

Rahmani, R., \& Abbas, M. (2014). The Influence of Single-gender Peer Scaffolding in Problem-based Gaming on Performance in Double-loop Learning and Sub-dimensions of Science Process Skills. Procedia - Social and Behavioral Sciences, 116, 41034107. https://doi.org/10.1016/j.sbspro.2014.01.898

Rahmani, R., Abbas, M., \& Alahyarizadeh, G. (2013). The Effects of Peer Scaffolding in Problem-based Gaming on the Frequency of Double-loop Learning and Performance in Integrated Science Process Skills. Procedia - Social and Behavioral Sciences, 93, 1994-1999. https://doi.org/10.1016/j.sbspro.2013.10.154

Stonewater, J. K., \& Wolcott, S. K. (2005). Two Rubrics for Critical Thinking Assessment: A Mini-Training Session Participant Outcomes : Identify Learning Outcomes for Critical Thinking, $1-20$.

Tajalli, P., \& Satari, S. (2013). Effectiveness of Metacognitive Strategies on Reading Skills of Students with Hearing Disorders. Procedia - Social and Behavioral Sciences, 84, 139-143. https:// doi.org/10.1016/j.sbspro.2013.06.524

Yuliana, R., Karyanto, P., \& Marjono. (2013). The Influence of Utilization Concept Map in Constructivisme Type Novick Model towards Misconception on The Concept of the Human Respiratory System. Bio-Pedagogi, 2(2), 45-57. Retrieved from http://www.jurnal.fkip.uns.ac.id/index.php/pdg/article/ viewFile/5521/3865 
Zhussupova, R., \& Kazbekova, M. (2016). Metacognitive Strategies as Points in Teaching Reading Comprehension. Procedia Social and Behavioral Sciences, 228(June), 593-600. https:// doi.org/10.1016/j.sbspro.2016.07.091

ŽivkoviL, S. ( $(\cdot 11)$. A Model of Critical Thinking as an Important Attribute for Success in the IIst Century. Procedia - Social and Behavioral Sciences, 232(April), 102-108. https://doi. org/10.1016/j.sbspro.2016.10.034 